University of Nebraska - Lincoln

DigitalCommons@University of Nebraska - Lincoln

USDA National Wildlife Research Center - Staff Publications
U.S. Department of Agriculture: Animal and Plant Health Inspection Service

2018

\title{
Prevalence and amount of feral swine damage to three row crops at planting
}

Richard M. Engeman

APHIS, s_r100@yahoo.com

Jason Terry

USDA/APHIS/WS

Leif R. Stephens

USDA/APHIS/WS

Kenneth S. Gruver

USDA/APHIS/WS

Follow this and additional works at: https://digitalcommons.unl.edu/icwdm_usdanwrc

Part of the Life Sciences Commons

Engeman, Richard M.; Terry, Jason; Stephens, Leif R.; and Gruver, Kenneth S., "Prevalence and amount of feral swine damage to three row crops at planting" (2018). USDA National Wildlife Research Center - Staff Publications. 2154.

https://digitalcommons.unl.edu/icwdm_usdanwrc/2154

This Article is brought to you for free and open access by the U.S. Department of Agriculture: Animal and Plant Health Inspection Service at DigitalCommons@University of Nebraska - Lincoln. It has been accepted for inclusion in USDA National Wildlife Research Center - Staff Publications by an authorized administrator of DigitalCommons@University of Nebraska - Lincoln. 


\title{
Prevalence and amount of feral swine damage to three row crops at planting
}

\author{
Richard M. Engeman ${ }^{\mathrm{a}, *}$, Jason Terry ${ }^{\mathrm{b}}$, Leif R. Stephens ${ }^{\mathrm{b}}$, Kenneth S. Gruver ${ }^{\mathrm{b}}$ \\ a National Wildlife Research Center, 4101 LaPorte Ave, Fort Collins, CO 80521-2154, United States \\ ${ }^{\mathrm{b}}$ USDA/APHIS/WS, 602 Duncan, Auburn, AL 36849, United States
}

A R T I C L E I N F O

\section{Keywords:}

Alabama

Corn

Cotton

Invasive species

Peanuts

Sus scrofa

Wildlife damage management

\begin{abstract}
A B S T R A C T
Feral swine damage to corn, cotton and peanut crops at planting was assessed for 46 fields in Alabama. Damage was assessed on the basis of prevalence among fields and the quantity lost within each damaged field. Feral swine control by professionals dedicated to that task appeared to greatly reduce the prevalence of damage among fields, as the 14 fields which were within the areas where professional swine control operations took place were not damaged. For the 32 fields not receiving such protection, seven (21.9\%) received some level of damage. Of those, $40 \%$ (four of 10 ) peanut fields, $15.4 \%$ (two of 13 ) cotton fields, and $11.1 \%$ (one of nine) corn fields were damaged. Damage levels were highly variable, both between and within crops. Losses were typically low $<1.3 \%$, but there were very notable exceptions where more substantial losses were incurred. One peanut field experienced a loss of $54.2 \%$ representing $32,401 \mathrm{~kg}$ of crop lost, valued at $\$ 15,779$. Feral swine damage to freshly planted row crops has previously received little, if any, in-field quantification in the literature, with this study possibly being the first of its kind.
\end{abstract}

\section{Introduction}

Feral swine (Sus scrofa; other common names include wild boar, wild/feral hog, and wild/feral pig; Keiter et al., 2016) are destructive invasive animals in North America. Their presence on the continent can be traced to introductions by early European explorers, beginning in 1539 with introductions by the Spanish explorer Hernando de Soto in Florida (Towne and Wentworth, 1950). Many deliberate and inadvertent introductions have ensued over the years (Belden and Frankenberger, 1977; Mayer and Brisbin, 1991; Towne and Wentworth, 1950), and now invasive feral swine populations are found in at least 35 of the 50 states in the USA (Corn and Jordan, 2018; Snow et al., 2017; U.S. Department of Agriculture, 2016). Globally, feral swine also are one of the world's most destructive invasive species, thereby earning their inclusion as one of the 100 "World's Worst" invaders by the IUCN Invasive Species Specialist Group (Lowe et al., 2004). They are infamous for their damage to native plant and animal species, habitats, as well as archaeological sites (Choquenot et al., 1996; Engeman et al., 2007, 2013a, 2016, 2017; Seward et al., 2004; U.S. Department of Agriculture, 1999, 2015, 2016). They also carry diseases transmissible to livestock, wildlife, or humans (e.g., Corn et al., 2005; Leiser et al., 2013; U.S. Department of Agriculture, 2015, 2016; Wyckoff et al., 2009). Making matters worse, feral swine have the highest reproductive potential of all large wild mammals in North America, matching their destructive capabilities with their reproductive vigor (Bieber and Ruf,
2005; Hellgren, 1999; West et al., 2009; Wood and Barrett, 1979).

Crop losses form one of the primary damage issues posed by feral swine (e.g., Seward et al., 2004; U.S. Department of Agriculture/Animal and Plant Health Inspection Service, 2015), with the most commonly damaged field crops including corn, peanuts, grain sorghum, wheat, oats, sugar cane, and rice, among many others (U.S. Department of Agriculture/Animal and Plant Health Inspection Service, 2015). Collectively, states with a confirmed feral swine population account for $60-80 \%$ of row crop production in the US (NASS, 2014). Crop fields offer high concentrations of highly digestible plants, and often become a highly preferred source of food for feral swine (Ditchkoff and Mayer, 2009). Feral swine may travel considerable distances for such desirable foods, having been found in one study to travel nearly $10 \mathrm{~km}$ to feed on sorghum (Mungal, 2001). Near croplands, feral swine densities can be fourfold higher than they would have been otherwise (Caley, 1993). Agricultural crops have been found to comprise as much as $71 \%$ of plant material consumed by feral swine (Mayer and Brisbin, 2009). Crops adjacent to riparian areas, a preferred habitat for feral swine, are particularly prone to being damaged. Damage is produced by consumption, rooting, digging, and trampling of crops (Seward et al., 2004).

Most information generated on crop losses to feral swine has originated as a result of surveys of farmers/producers across various geographic scales where producers have answered questionnaires about feral swine impacts to their crops (e.g., Anderson et al., 2016; Mengak,

\footnotetext{
* Corresponding author.

E-mail address: richard.m.engeman@aphis.usda.gov (R.M. Engeman).
} 
2012, 2016; NASS, 2018a; Ober et al., 2011). For example, in one of the most comprehensive surveys on feral swine damage, Anderson et al. (2016) recently found that the highest yield loss estimates were in peanut and corn production in Texas and the Southeast. Within-state surveys have produced comparable results. A survey in Texas found that the most common $(75 \%)$ issue with feral swine was damage to agricultural crops including hay, corn, peanuts, and small grains like milo, rice, and wheat (Rollins, 1993). Respondents to a questionnaire in Georgia averaged $\$ 12,646$ per respondent in crop losses by feral swine during 2011 (Mengak, 2012) and $\$ 6780$ in 2015 with total crop losses for the state estimated as \$98, 870, 961 (Mengak, 2016), and in 2009 feral swine damage losses across 29 counties in northern Florida were estimated at $\$ 314,739$ for corn, $\$ 327,943$ for cotton, $\$ 1,151,178$ for peanuts, and $\$ 30,815$ for soybeans (Ober et al., 2011).

Actual in-field damage measurements are comparatively uncommon as they require a substantially greater investment in resources, labor, and coordination with farmers. Hence, there are relatively few studies that measure crop losses to feral swine over a number of fields, especially encompassing multiple crops. Even rarer seem to be quantifications of losses to feral swine at planting, and this may be the first presentation of such data. We examined 46 fields to provide information on: 1) the prevalence of feral swine damage to freshly planted fields of corn, cotton, and peanuts, and 2) measures of the amounts of damage when it occurs.

\section{Methods}

\subsection{Crop fields}

Forty-six fields from three counties (Coffee, Dale and Henry Counties) in Alabama were examined for feral swine damage at planting. Fields ranged in size from 1.4 to 56.8 ha $(\bar{X}=15.1$ ha, $\mathrm{SE}=1.6 \mathrm{ha})$. Three crops were represented among these fields: corn (10 fields), cotton (25 fields), and peanuts ( 11 fields). Of the 46 fields, 14 were subject to protection by feral swine removal conducted by U.S. Department of Agriculture/Wildlife Services (WS), the Federal agency responsible for managing conflicts with wildlife (U.S. Department of Agriculture/Animal and Plant Health Inspection Service et al., 1997). Agreements with WS to provide feral swine control were formed because of past history of feral swine damage in those areas. Of these protected fields, one was planted with corn, two with peanuts, and 11 with cotton. Thus, the fields receiving protection through feral swine control would presumably be inherently more susceptible to receiving damage due to their past damage histories. WS controlled feral swine using only approved and humane methods to euthanize animals that conformed to the guidelines laid out in the 2000 Report of the American Veterinary Medical Association Panel on Euthanasia (American Veterinary Medical Association, 2013) and set forth as agency policy in USDA/APHIS/WS Directive 2.505. The two primary methods applied to remove feral swine were trapping and sharpshooting.

Feral swine damage to each crop was quantified in two ways: 1) the prevalence of damage among protected and unprotected fields of each crop, and 2) the amount of damage within each of the fields with damage.

Considering that the fields at planting are essentially bare soil without vegetative cover, feral swine rooting along the rows is readily detectable. After crops have been planted, damage can occur on any given day, with the chance of damage to planted seeds reduced as the plants grow. Discussions with farmers indicated that the majority of planting-time damage occurs in the first 10 days to two weeks after planting, and some damaged sections in fields may be replanted during that time period if damage is severe. Thus, there was a potential for some information to be lost if damage was measured only once postplanting. Each field was observed twice to assess how quickly planted fields were damaged, whether or not farmers felt the need to replant, and to assess if replanting actually overcame the damage. As coordination with farmers' schedules allowed, damage assessments were targeted for five and 10 days post-planting, although timing of observations required flexibility due to the logistics of observing a large number of fields in three counties and communication with farmers on planting schedules.

Observations on whether or not each field had been damaged provided information on the prevalence of damage among protected and unprotected fields of each crop type. The prevalence of damaged fields was compared among the three crops using Fishers "exact" test.

\subsection{In-field damage sampling}

The general concept for determining damage levels for the rooted fields was to estimate the total length of all rows combined, measure all damaged crop row segments in the field, and sum those damage lengths into a combined value for the field. The combined damage segment lengths divided by the estimated combined lengths of all rows in the field provided an estimate of proportion of crop lost (also described in Engeman, 2017). Estimation of the total combined length of all rows in a field required basic information concerning the field size and row spacing. The area of each field was defined by riding the field's perimeter on an all-terrain vehicle (ATV) while a GPS mapped the field and ultimately calculated its area. Dividing the row width into the field area provides an estimate of the total combined lengths of all rows (this avoided measuring the lengths of all rows in the field).

Locating damage was accomplished by searching for damage while slowly driving the perimeter of the field, with damage readily visible in the bare soil of the fields after planting. Each time damage was located it was measured and the length of each row segment of rooting damage was recorded. After all damaged segments in the field were recorded, they were summed to arrive at the total row length rooted in the field. It was also noted if the field had been replanted. If a field was replanted between assessments and further damage occurred in the replanted field, then this was recorded too. The proportion of the field damaged was calculated as the summed length of all damage segments divided by the total combined lengths of all rows in the field. If the field had not been replanted, then the damage proportion at the second assessment represented the cumulative damage to that point. If the field had been replanted (and assuming no further replanting occurred after the second assessment), then the damage at the second assessment represented the proportion of the field that could not grow and eventually be harvested, but the cumulative damage that had taken place to that point was the combined damage at the first and second assessments.

\section{Results}

The prevalence of damage to fields among crops, and whether or not they were in areas receiving control by WS are summarized in Table 1. Over all crops, seven of the 32 fields (21.9\%) not within areas protected by WS feral swine control experts received some level of damage. None of the 14 fields within areas receiving WS control received damage. With four of 10 fields damaged, peanut fields were much more likely to have received damage than fields planted with corn (one of nine) or

Table 1

The prevalence of feral swine damage at planting to fields with corn, cotton and peanuts in areas with and without feral swine control by U.S. Department of Agriculture/Wildlife Services in three Alabama counties.

\begin{tabular}{llllll}
\hline \multirow{2}{*}{ Crop } & Protected by control & Not Protected by control & \multirow{2}{*}{ Total } \\
\cline { 2 - 5 } & \# Damaged & \# Undamaged & \# Damaged & \# Undamaged & \\
\hline Corn & 0 & 1 & $1(11.1 \%)$ & 8 & 10 \\
Cotton & 0 & 11 & $2(15.4 \%)$ & 11 & 24 \\
Peanut & 0 & 2 & $4(40.0 \%)$ & 6 & 12 \\
Total & 0 & 14 & $7(21.9 \%)$ & 25 & 46 \\
\end{tabular}


Table 2

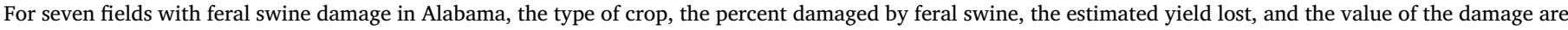

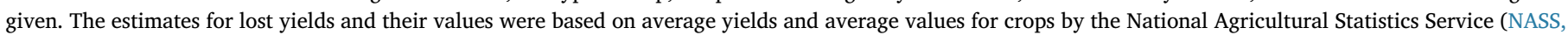
2018a, 2018b).

\begin{tabular}{|c|c|c|c|c|c|c|c|}
\hline Field\# & crop & Field size (ha) & Assessment & Damage $\%$ (\% linear row-lengths planted) & Replanted between assessment & Estimated yield lost & Estimated value lost \\
\hline \multirow[t]{2}{*}{1} & corn & 18.3 & 1 & 0.74 & & & \\
\hline & & & 2 & 1.28 & no & $96.56 \mathrm{bu}$ & $\$ 386.26$ \\
\hline \multirow[t]{2}{*}{2} & cotton & 30.2 & 1 & 0.00 & & & \\
\hline & & & 2 & 0.07 & no & $20.27 \mathrm{~kg}$ & $\$ 30.61$ \\
\hline \multirow[t]{2}{*}{3} & cotton & 21.8 & 1 & 0.11 & & & \\
\hline & & & 2 & 0.17 & no & $36.48 \mathrm{~kg}$ & $\$ 55.08$ \\
\hline \multirow[t]{2}{*}{4} & peanut & 20.3 & 1 & 0.00 & & & \\
\hline & & & 2 & $<0.01$ & no & $<2.39 \mathrm{~kg}$ & $<\$ 1.17$ \\
\hline \multirow[t]{2}{*}{5} & peanut & 13.6 & 1 & 1.12 & & & \\
\hline & & & 2 & 1.24 & no & $688.45 \mathrm{~kg}$ & $\$ 335.28$ \\
\hline \multirow[t]{2}{*}{6} & peanut & 15.6 & 1 & 7.61 & & & \\
\hline & & & 2 & $0.59^{\mathrm{a}}$ & yes & $376.37 \mathrm{~kg}$ & $\$ 183.29$ \\
\hline \multirow[t]{2}{*}{7} & peanut & 14.6 & 1 & 6.07 & & & \\
\hline & & & 2 & $54.23^{\mathrm{a}}$ & yes & $32400.72 \mathrm{~kg}$ & $\$ 15779.15$ \\
\hline
\end{tabular}

a The damage proportion at the second assessment for the two fields that were replanted represents the proportion of the crop damaged at that time (like for fields not replanted), but the total amount of damage that actually took place would be the combined damage amounts observed at the first and second assessments.

cotton (two of 13) (Table 1, Fisher's "exact" test $\mathrm{p}=0.044$ ).

Over all fields and crops, the levels of damage observed varied greatly (Table 2), from less than $.01 \%$ in a peanut field to $54.2 \%$ in another peanut field. At the first assessment, the single corn field with damage had $0.74 \%$ of its planted rows rooted, with cumulative damage of $1.28 \%$ measured at the second assessment. The smaller of the two damaged cotton fields ( $21.8 \mathrm{ha}$ ) had a higher proportion of crop lost ( $0.17 \%$ or 0.037 ha lost), and the larger of the two fields ( $30.2 \mathrm{ha}$ ) had $0.07 \%(0.020$ ha) damaged. The proportion of the field damaged varied widely for peanuts, ranging from $<0.01 \%$ to $54.2 \%$, which translated to a range of $<0.01$ ha-7.92 ha lost to damage (Table 2).

Regardless of crop, all fields with damage at the first assessment received additional damage prior to the second assessment. Two peanut fields were replanted between assessments, and both received damage after replanting. One field, Field 6 in Table 2, had 7.61\% of the field damaged at the first observation session, with only an additional $0.59 \%$ damaged after replanting. Thus, replanting the field appeared to overcome the initial damage. The same was not true of the other field that was replanted, Field 7 in Table 2 . At $6.1 \%$ damaged at the first assessment, its damage percent was similar, but slightly less to that for Field 6 . However, $54.2 \%$ of the field was subsequently damaged after it was replanted.

In Alabama, the 2017 average crop yields were $4091 \mathrm{~kg} / \mathrm{ha}$ for peanuts, $412.67 \mathrm{bu} / \mathrm{ha}$ for corn, and $1013.26 \mathrm{~kg} / \mathrm{ha}$ for cotton (NASS, 2018a). The average prices for these crops were \$USD $0.487 / \mathrm{kg}$ for peanuts, \$USD 4.00/bu for corn, and \$USD $1.51 / \mathrm{kg}$ for cotton (NASS, 2018a, 2018b). The estimated yields lost to feral swine damage and the estimated values of the lost production for each of the fields with damage are also given in Table 2. The estimated values of potential lost crops per field ranged from less than \$USD 1.17 to \$USD 15,779.15, with both extremes occurring in peanut fields. The single corn field with damage had a potential lost yield valued at \$USD 386.26, while the lost yields from both cotton fields with damage were \$USD 55.08 or less.

\section{Discussion}

Planting is the first opportunity in the crop cycle for feral swine to damage row crops. All three crops we examined are well-known to suffer damage by feral swine (e.g., U.S. Department of Agriculture/ Animal and Plant Health Inspection Service, 2015). Anderson et al. (2016) found that $29 \%$ of respondents in Alabama had feral swine damage to crops. We found that $21.9 \%$ (seven of 32) of fields not in an area receiving professional feral swine control had feral swine damage just at planting (Table 1). If we include the additional 14 fields that received control and had no damage, then $15.2 \%$ (seven of 46 ) of fields had damage at planting. Because these percentages cannot decrease by harvest time and the crops remain available for further damage through harvest, it seems the damage prevalence in the three county region of our study could exceed that found by Anderson et al. (2016) by harvest time.

Since the prevalence of damaged fields was much higher for peanuts than corn or cotton (Table 1), the temptation would be to infer that this information is sufficient to conclude that peanuts at planting would be preferred by feral swine over corn or cotton seed. However, to validly make such an inference with certainty would require a designed choice test among the crops to indicate a preference. Nevertheless, we noted that feral swine tracks leading from nearby woods first crossed cotton fields where no damage was observed to reach the two peanut fields damaged sufficiently to be replanted. This would seem to provide evidence that the feral swine in the vicinity of these fields found freshly planted peanuts more attractive than cotton seeds. Because corn fields were planted on average over a month earlier than the peanut and cotton fields, similar observations could not be made between corn and either of the other two crops.

Peanuts followed by corn suffered the highest yield losses to feral swine damage among the crops Anderson et al. (2016) studied in an eleven state survey. Cotton was not included in that study. Across all combinations of crops and states studied by Anderson et al. (2016), the highest mean reported damage occurred in peanut production in Texas (9.28\%) and Alabama (6.17\%), although the prevalence of damage for peanuts was not reported. If we only consider the 10 peanut fields in our study that were not protected through WS control, then the mean yield loss for feral swine damage at planting was $5.61 \%$. If we include into the calculation of a mean damage amount the two peanut fields with professional feral swine control and no damage, then the average damage among our studied peanut fields would be $4.67 \%$. Thus, at least in the three county region we studied, the additional damage that would likely occur prior to harvest would also likely increase the mean peanut losses above the $6.17 \%$ found by Anderson et al. (2016) for Alabama. Clearly, having one field out of 10 exhibit a $54.2 \%$ loss even with replanting greatly influenced the mean percent damage. Yet, this is often the nature of animal damage where it can be generally light in most places, but some locations can suffer very extensive losses and have a substantial economic impact on the producer (Table 2).

The survey by Anderson et al. (2016) found that the average yield of corn lost to feral swine damage in Alabama was $0.93 \%$. We found damage in only one corn field (unprotected by control) with a yield loss of 
$1.28 \%$. Considering only the fields without feral swine control, the average yield loss was $0.16 \%$, while including the single corn field receiving feral swine control reduces the average yield loss to $0.14 \%$. While both of these figures are much smaller than the figure obtained by Anderson et al. (2016), we again have to consider that as corn grows and matures feral swine will use corn fields for both refuge and forage, both of which can lead to substantial losses.

Both cotton fields with damage only had very minor damage. As further testament that cotton seeds may not be preferred by feral swine as forage, the rooting that we did see in these cotton fields (and other cotton fields in our experience) was targeting grasses with the planted rows of cotton seeds being collateral damage to this rooting. Grasses and forbs are important components of the springtime diets of feral swine (e.g., Mapston, 2004; Mayer and Brisbin, 2009), and an abundance of such grasses in a field might be a signal that the field is vulnerable to rooting by feral swine.

It is not surprising to see highly variable damage across the landscape. Wildlife do not exist or move uniformly across the landscape. The damage levels we observed at planting across most (five of the seven) of the damaged fields were less than $1.25 \%$. However, like with many wildlife damage situations, feral swine damage to crops can be locally severe, and we observed one field of peanuts with $54.2 \%$ of the planted peanuts lost. Variability in damage levels is also exacerbated because feral swine may travel in social unit sizes ranging from solitary individuals (typically sexually mature boars) to large groups in sounders, family groups typically of nine or fewer animals comprised of two or more adult sows and their offspring (e.g., U.S. Department of Agriculture, 2015). However, sounders have been reported to come together to include up to 40 or 50 animals (Mapston, 2004; Mayer, 2009). When a sounder forages in a crop field there might be a large number of individuals rooting at the same time, thereby causing large amounts of damage very quickly. For example, a single group of feral swine was observed to destroy a 10-acre cornfield in less than a week (Gates, 2012).

The fields protected by WS control experienced no damage at planting, even though their histories of receiving damage would likely predispose them to damage. Of course, it would be unreasonable to expect that all fields in the vicinities of such control activities would remain damage-free, but it is reasonable to expect that the probability of damage would be (much) reduced. Most farmers will opportunistically remove feral swine, but their overriding focus must remain on farming the land. Whereas, professional control experts are highly experienced at control and are focused specifically on control activities, thereby allowing efficacy to be maximized. Besides the value of lost crop production through damage, the economic impacts inflicted by feral swine also include the costs of feral swine control or other mitigation procedures like electric fencing. The decision to hire professionals to carry out feral swine control involves weighing the potential costs of lost production with costs for control. The fields in our study receiving WS feral swine control had histories of damage, meaning the farmers assessed in advance that the costs associated with forming control agreements with WS would be less than costs from lost production due to damage. Notably, the damage levels to the two peanut fields that prompted replanting subsequently induced those farmers to invest in a cost-share agreement for WS to control feral swine there too.

This study provides a demonstration of the extent and nature of feral swine damage to three crops in three counties in Alabama. Without suggesting that these results are a quantitative representation of all feral swine damage at planting, they do provide valuable takeaway points. First, feral swine damage to freshly planted row crops has previously received little, if any, in-field quantification in the literature. Second, as would be expected, damage was highly variable, both between and within crops. Third, damage percentages tended to be minor in most fields, but exceptions can occur where substantial yield and economic losses result. Fourth, replanting a field won't necessarily overcome damage, as further and greater damage may still occur in the replanted field. Fifth, feral swine control by professionals dedicated to that task appeared to greatly reduce the prevalence of damage among fields.

\section{References}

Anderson, A., Slootmaker, C., Harper, E., Holderieath, J., Shwiff, S.A., 2016. Economic estimates of feral swine damage and control in 11 US states. Crop Protect. 89, 89-94. American Veterinary Medical Association, 2013. AVMA Guidelines for the Euthanasia of Animals: 2013 Edition. American Veterinary Medical Association, Schaumburg, IL.

Belden, R.C., Frankenberger, W.G., 1977. Management of feral hogs in Florida - past, present, and future. In: Wood, G.W. (Ed.), Research and Management of Wild Hog Populations. Clemson University, pp. 5-10.

Bieber, C., Ruf, T., 2005. Population dynamics in wild boar Sus scrofa: ecology, elasticity of growth rate and implications for the management of pulsed resource consumers. J. Appl. Ecol. 42, 1203-1213.

Caley, P., 1993. Population dynamics of feral pigs (Sus Scrofa) in a tropical riverine habitat complex. Wildl. Res. 20, 625-636.

Choquenot, D., McIlroy, J., Korn, T., 1996. Managing Vertebrate Pests: Feral Pigs. Bureau of Resource Sciences. Australian Government Publishing Service, Canberra, ACT.

Corn, J.L., Cumbee, J.C., Chandler, B.A., Stallknecht, D.E., Fischer, J.R., 2005. Implication of feral swine expansion: expansion of feral swine in the United States and potential implication for domestic swine. In: Feral Swine Subcommittee on Brucellosis and Pseudorabies. United States Animal Health Association, St. Joseph, MO, pp. 295-297.

Corn, J.L., Jordan, T.R., 2018. Development of the national feral swine Map, 1982-2016. Wildl. Soc. Bull. 41, 758-763.

Ditchkoff, S.S., Mayer, J.J., 2009. Wild pig food habits. In: Mayer, J.J., Brisbin Jr.I.L. (Eds.), Biology, Damage Control Techniques and Management. SRNL-rp-2009-00869. Savannah River National Laboratory, Aiken, SC, pp. 105-144.

Engeman, R.M., 2017. Estimating feral swine damage to row crops just after planting. In: General Procedural Guide for WS-operations to Implement Practical Damage Estimation. Wildlife Services Tech Note, Part of the WS Damage Assessment Series. USDA, APHIS, WS National Wildlife Research Center. Ft. Collins, Colorado.

Engeman, R.M., Addison, D., Griffin, J.C., 2016. Defending against disparate sea turtle nest predators: benefits to nesting success from eradicating invasive feral swine and caging nests from raccoons. Oryx 50, 289-295.

Engeman, R.M., Couturier, K.J., Felix Jr., R.K., Avery, M.L., 2013. Feral swine disturbance at important archaeological sites in Florida. Environ. Sci. Pollut. Control Ser. 20, 4093-4098.

Engeman, R.M., Meyer, J.S., Allen, J.B., 2017. Prevalence of feral swine disturbance at important archaeological sites over a large area in Florida. Sci. Rep. 740287.

Engeman, R.M., Stevens, A., Allen, J., Dunlap, J., Daniel, M., Teague, D., Constantin, B.U., 2007. Feral swine management for conservation of an imperiled wetland habitat: Florida's vanishing seepage slopes. Biol. Conserv. 134, 440-446.

Gates, V., 2012. Hog Wild: Feral Pig Population Explodes in US. Chicago Tribune, June 22, 2012. (Chicago, IL).

Hellgren, E., 1999. Reproduction in feral swine. In: Proceedings of the 1999 National Feral Swine Symposium. Texas Animal Health Commission, Austin, Texas, pp. 67-68.

Keiter, D.A., Mayer, J.J., Beasley, J.C., 2016. What's in a "common" name? A call for consistent terminology for non-native Sus scrofa. Wildl. Soc. Bull. 40, 384-387.

Leiser, O.P., Corn, J.L., Schmit, B.S., Keim, P.S., Foster, J.T., 2013. Feral Swine Brucellosis in the United States and Prospective Genomic Techniques for Disease Epidemiology Veterinary Microbiology, vol. 166. pp. 1-10.

Lowe, S., Browne, M., Boudjelas, S., De Poorter, M., 2004. 100 of the World's Worst Invasive Alien Species a Selection from the Global Invasive Species Database. Invasive Species Specialist Group, Auckland.

Mapston, M.E., 2004. Feral Hogs in Texas. AgriLife Communications and Marketing. Texas A\&M System, College Station.

Mayer, J.J., 2009. Wild pig behavior. In: Mayer, J.J., Brisbin Jr.I.L. (Eds.), Biology, Damage Control Techniques and Management. SRNL-rp-2009-00869. Savannah River National Laboratory, Aiken, SC, pp. 77-104.

Mayer, J.J., Brisbin Jr., I.L., 1991. Wild Pigs in the United States. University of Georgia Press, Athens, GA.

Mayer, J.J., Brisbin Jr., I.L., 2009. In: Wild Pigs: Biology, Damage, Control Techniques and Management. SRNL-rp-2009-20000869. Savannah River National Laboratory, Aiken, SC.

Mengak, M., 2012. Georgia wild Pig Survey Final Report. Warnell School of Forestry and Natural Resources. University of Georgia, Athens, GA.

Mengak, M., 2016. 2015 Georgia Wild Pig Survey Final Report. Warnell School of Forestry and Natural Resources. University of Georgia, Athens, GA.

Mungal, E.C., 2001. Exotics. In: Demarais, S., Krausman, P.R. (Eds.), Ecology and Management of Large Mammals in North America. Prentice Hall, Upper Saddle River, NJ, pp. 736-764.

NASS (National Agricultural Statistics Service), 2018a. Southern Region news release: Annual Crop Production. United States Department of Agriculture/National Agricultural Statistics Service. Southern Regional Field Office, Athens, GA.

NASS (National Agricultural Statistics Service), 2018b. Southern region news release: Crop Values. United States Department of Agriculture/National Agricultural Statistics Service. Southern Regional Field Office, Athens, GA.

Ober, H.K., Edmondson, G.R., Giuliano, W.M., Wright, D.L., Atkins, J., Andreasen, A. Eubanks, S., Johnson, L., Brasher, C., Hicks, G., 2011. Farmer Perceptions of Wildlife Damage to Row Crops in North Florida, vol. 311 Florida Cooperative Extension Service Publication WEC, Gainesville, FL. 
Rollins, D., 1993. Statewide attitude survey on feral hogs in Texas. In: Hanselka, C.W., Cadenhead, J.F. (Eds.), Feral Swine: a Compendium for Resource Managers. Texas Agricultural Extension Service, Kerrville, TX, pp. 1-8.

Seward, N., VerCauteren, K., Witmer, G., Engeman, R.M., 2004. Feral swine impacts on agriculture and the environment. Sheep Goat Res. J. 19, 34-40.

Snow, N.P., Jarzyna, M.A., VerCauteren, K.C., 2017. Interpreting and predicting the spread of invasive wild pigs. J. Appl. Ecol. 54, 2022-2032.

Towne, C.W., Wentworth, E.N., 1950. Pigs from Cave to Cornbelt. University of Oklahoma Press, Norman, Oklahoma.

U.S. Department of Agriculture, 1999. Wild Pigs Hidden Danger for Farmers and hunters. Animal and Plant Health Inspection Services Information Bulletin 620, Washington, D.C.

U.S. Department of Agriculture, 2016. Feral Swine: Damages, Disease Threats, and Other Risks. Animal and Plant Health Inspection Services Program Aid 2195b (Washington, D.C).
U.S. Department of Agriculture/Animal and Plant Health Inspection Service, 2015. Final Environmental Impact Statement Feral Swine Damage Management: a National Approach. USDA/Animal and Plant Health Inspection Service, Washington, D.C.

U.S. Department of Agriculture/Animal and Plant Health Inspection Service, 1997. U.S. Department of agriculture/Forest Service and Department of Interior/Bureau of land management. Animal Damage Control Program Final Environmental Impact Statement (Revised). USDA/Animal and Plant Health Inspection Service, Washington, D.C.

West, B.C., Cooper, A.L., Armstrong, J.B., 2009. Managing wild pigs: a technical guide. Human-Wildlife Interactions 1, 1-55.

Wood, G.W., Barrett, R.H., 1979. Status of wild pigs in the United States. Wildl. Soc. Bull. 7, 237-246.

Wyckoff, A.C., Henke, S.E., Campbell, T.A., Hewitt, D.G., VerCauteren, K.C., 2009. Feral swine contact with domestic swine: a serologic survey and assessment of potential for disease transmission. J. Wildl. Dis. 45, 422-429. 